\title{
The Impact of Board Composition on Corporate Dividends Pay-Out: "An Empirical Examination of Industrial Companies Listed in Amman Stock Exchange"
}

\author{
Dr. Abeer Atallah Aloudat ${ }^{1 *} \quad$ Hazar Tawfeq Almohammadi Mohammad Awni Ahmad \\ Accounting department, College of Applied Studies and community services, Imam Abdulrahman bin Faisal \\ University (KSA), 2019
}

\begin{abstract}
This study investigates the impact of board composition on corporate dividends pay-out of a sample of 30 Jordanian industrial companies listed on the Amman Stock Exchange (ASE) during the period (2007-2017). The study examine the impact of a certain variables that represent board composition (Board size , Independent (non-executive ) director, duality of chief executive officer (CEO) and chairman position, Director nationality , Institutional investors ) .Panel-Data analysis was used to test the empirical model in the current study using a fixed affect model and Random effect model. Relevant data were collected from the (ASE) website and from the annual reports of the sampled companies. The result of the study revealed that there is a negative significant effect between Institutional investors, audit firm and dividend per share (DPS) at the 1\% level. Moreover, there is a negative significant effect between Independent director and DPS at the 5\% level. In contrast, board of director size and firm profitability positively affect the DPS at the 5\% level. Furthermore, Duality of CEO and chairman position, director nationality, firm size and financial leverage were found to have no effect on DPS at the $5 \%$ level.
\end{abstract}

Keywords: Board Composition, Corporate Governance, Pay-out, ASE

DOI: $10.7176 / \mathrm{EJBM} / 11-27-16$

Publication date:September $30^{\text {th }} 2019$

\section{Introduction}

The system of corporate governance is introduced to solve agency cost and minimize manager tendency toward pursuing objective that lead to harm stockholder wealth (Joshua Abor, Vera Fiador, 2013) The characteristic of board of director and the important role played by them in monitoring the firm consider an important corporate governance mechanism. (John and Senbet, 1998).

The board has the obligation to determine the firm's overall strategy, and to ensure that adequate controls are in place to protect shareholder value (Keenan, 2004). This study focuses on one of such decisions of corporate boards - the dividend pay-out decision. There is an important need to understand the central drivers of corporate dividend pay-out in Jordan. Therefore, this study seek to contribute to the extant literature by investigating the impact of board composition on dividend pay-out of Jordanian listed industrial companies during period of 2007-2017.

A dividend policy could make significant impact on the corporate future value when it is well established and carefully followed. Corporate governance should institute an effective mechanism of how much and when to pay as share dividends, taking into account a variety of factors relating to the company's current status, its future as well as market and economic circumstances (Abdulrahman, 2007). Beside this decision company must ensure competitive position sustainability to attract capital and to combat corruption and in order to achieve this goal companies need to take in consideration good governance practices (Abdelkareem, 2013).

Effective corporate governance and dividend payout policy are very important components of every company, this is vital to ensure the credibility of internal control and monitor the financial affairs of stockholder rightfully, thus, the research problem can be expressed through the following question:

Is there an impact of board composition (board size, CEO duality, board independence, board nationality, institutional investor) on dividends payout of Jordanian industrial companies listed on the ASE during the period of 2007-2017?

\section{Literature review}

(Adjaoud and Hermassi, 2017) explore the impact of board composition, board independence and CEO duality on the dividend policy. Using 117- Canadian firms listed on the Toronto Stock Exchange during the period 20082011.Researchers examine the relationship between dividend pay-out and governance mechanisms using logistic regressions where the dependent variable is the chance of the firm to pay or not pay a dividend to shareholders.

The researchers included variables related to profitability, leverage, growth opportunities and firm size. The results declared that the likelihood to pay dividends is impacted strongly by board composition, board 
independence and CEO duality. (Mehdi, et al., 2017) tested whether the effects of corporate governance on dividend policy change during crisis periods using a panel regression approach on a sample of 362 non-financial listed firms from East Asian and Gulf Cooperation Council countries and found that dividend pay-out decision increases with institutional ownership and board activity, they also found that in emerging countries, dividend policy of firms with CEO duality and without CEO duality does not depend on the same set of factors.

It is shown that the ownership concentration and board independency affect significantly the dividend policy of firms with CEO duality. Moreover the results show that during the recent financial crisis, dividend decision is negatively related to CEO duality, board size and the frequency of board meetings of board meetings. (Elmagrhi.et .al ,2017) examine the extent to which corporate board characteristics influence the level of dividend pay-out ratio using UK small- and medium-sized enterprises from 2010 to 2013 listed on the Alternative Investment Market by employing multivariate regression techniques, including estimating fixed effects, lagged effects and two-stage least squares regressions. The results show that board size, the frequency of board meetings, board gender diversity and audit committee size have a significant relationship with the level of dividend pay-out.

Audit committee size and board size have a positive association with the level of dividend pay-out, while the frequency of board meetings and board gender diversity have a significant negative relationship with the level of dividend pay-out.

(Abdel Razeg et al., 2016) examine the impact of Board of Directors composition and Audit Committee on stock returns, the board of directors and the audit committee are used to measure the corporate governance mechanisms. Within a fundamental analysis on the financial Jordanian companies' listed on the Amman Stock Exchange (ASE) over the period 2007 to 2012. The results revealed that there is a statistical relationship between stock return and each of the board of directors and the audit committee.

The researchers recommend the financial Jordanian companies to reduce the number of board of director's members, to adjust the proportion of the external directors and non-executive in each of the board of director and the audit committee. (Riaz, et al., 2016) investigate the influence of board composition (Board Size, Board Independence and Board Meetings) on dividend policies using Pakistani firms during the period of 2009 to 2015 ,By employing the regression analysis, Results indicate that Board size , Board independence and foreign ownership impact significantly the divided policies of the firm. They also observed that CEO ownership has significant negative influence on the dividend pay-out ratio of the firm due to entrepreneurial effect.

(Musa Shehu, 2015) examine the relationships between board characteristics and dividend pay-out ratio using 164 Malaysian public listed companies for the year 2013 ,Multiple regressions were used to examine the relationship between independent nonexecutive directors, board size, $\mathrm{CEO}$, proportion of family member on board and concentrated ownerships and dividend pay-out among the Malaysian listed companies.

Results shows that independent non-executive director and firm size have significant positive influence on dividend pay-out ratio .

However the relationship between dividend pay-out ratio and the board size and proportion of family members on the board was found insignificant and negative between dividend pay-out ratio and the board size and proportion of family members on the board. (Benjamin, Mat Zain, 2015) investigate whether corporate governance attributes are substitutes to control agency problem within the Malaysian context by examine the relationship between frequency of meetings and board independence with dividend pay-out. Using panel data on a sample of 114 Malaysian firms for seven years from 2002 to 2008.

esults show significant negative (inverse) relationship between (board independence, board meeting frequency) and dividend pay-out. Indicating that firms with weak corporate governance need to establish reputation by paying more dividends. Specifically, the findings indicate that firms with a higher proportion of independent directors and boards of director that meet more frequent pay lower dividends. (Yarram, Dollery, 2015) examine the influence of board structure on dividend policy using 413 non-financial Australian corporate firms during the period 2004-2009. The causal analysis was undertaken in three stages. In the first stage, the authors analyse the likelihood of paying dividends. And classify all firms as either dividend payers or non-payers.

The authors then model this binary variable as a function of different sets of variables. In the second stage, the authors analyze the factors determining the magnitude of dividend pay-out by those firms that have paid a dividend. In contrast, stage three employs all firms - those which did not pay any dividend and those firms which paid a dividend during. The result show that both of board independence and board size have a significant positive influence on the dividend pay-out of Australian firms.

(Al-rahahleh, 2015) tested the impact of corporate governance quality and gender diversity of dividends payout policy for all non- financial firms listed in ASE during the period 2009 to 2015, Ordinary Least Squares (OLS) regression analysis was performed, the results indicates that woman representative at board of director in Jordan is low and there is a positive association between the board of director composition of and dividends payout policy. (Paul McGuiness, et al., 2015) investigate the association between Chinese board characteristics and dividends policy using more than 9000 firm-year observation of Chinese firms. The researchers tested the 
gender of CEO, number of board members, board age, board independent on cash flow distributions, by employing the regression analysis, .the results indicates a difference in the dividend distributions of female- and male Chinese firms. It also show that the CEO age have significantly cash distributions.

However the results also show that greater independent director presence in firms acts as a brake against cash distributions.

Those previously mentioned studies support findings of La Porta 2000 that managers pay dividends as a result of good corporate governance and thus they manage free cash flow effectively and reducing agency cost enabling manager to make better decision that achieve share holder objective.

\section{Agency problem}

Agency problem as developed primarily by Jensen and Meckling (1976) is referring to the conflict of interest between principles and agents. This problem occurs due to separation between ownership and management. More specific, it arises when the shareholder assigns the power of the decision making to a manager while the last executes their duties on behalf of the shareholder (Jensen and Meckling, 1976). This transfer of decision control enhances managers to stop following the principle's instructions and intentionally perform improbably. In the sense that decision making may be directed for their own good rather than for shareholders' best interest.

However, inherent in any principle-agent relationship, it's expected that management assumes an obligation of loyalty to the owners thus management will not take personal advantage of the business opportunities the agency position uncovers, In turn, owners return confidence and trust in agent (Schulder ,2002) similarly, Miller and Modigliani (1958) ignored the presence of agency problem by assuming information are symmetries; where outsiders and insider have the same access to information relating performance and future prospect of the firm thus managers are not well informed or have better information advantage over outsider which make work on behalf shareholder effective. Creating no conflict of interest. By contrast (Malonis, 2000) argues that principle agent relationship that exists between management and owners contains some conflict similarly, (Myers and Majluf, 1984) argue that conflict between owners and managers is possible due to difference of information available for each party.

In order to solve this problem, the interest of the managers should be aligned with the interest of the shareholders. To accomplish this goal several mechanism can be used for instance: incentives and monitoring by principles (Seth , 1995) .However, (laffont ,2010) argue that it's so difficult for a principle to monitor the agent completely as result an information asymmetries might arise which eventually will increases the agency problem (janssen ,2009).

Asymmetric information problem arises as a result of information differences between insider and outsider so when good or bad news released in the market the investors who cannot distinguish between those two type of information will value the both at an average level, Therefore, well informed investors will make benefit of such a situation by mitigating the miss valuation problem (kreps, 1990). Agency problem and asymmetric information remained a conflict for all firms all over the world and a puzzle to academia until birth of corporate governance at 2000 .

\section{Sample, data and variables \\ Sample}

The population of this study includes all manufacturing companies listed on the Amman Stock Exchange (ASE) for the period 2007-2017 which is 55 companies. The reason behind the choice of the manufacturing sector is its importance for the Jordanian economy. It contributes to about $25 \%$ of Jordan GDP, suggesting that this sector have a large contribution to the GDP. However, the sample of the study contains all listed manufacturing companies for the period (2007-2017) for which all information needed to calculate the variables of the study is available. Of the 55 industrial companies listed on the ASE, 30 companies met the selection criteria and are included in the study sample.

Data

The data for this study come from secondary sources. Data needed to measure the variables of the study were taken from the sampled companies annual reports for the period (2007-2017). With respect to this, the annual reports for listed companies in Jordan are available on the ASE's website. Other data came from sources that are available in the internet, books and articles.

Variables

Dependent Variables

The dependent variable in this study is the "Dividends Pay-Out". This variable is measured by dividend per share (DPS), The aggregate declared dividends of a company paid out per year divided by number of common shares issued (Yarram, 2012).

$\mathrm{DPS}=$ dividends paid out per year /number of share outstanding. 
Independent and control variables and their measurement

Table (1) provides a summary of variables used by the study and their measurements.

Table 1: Summary of variables used by the study and their measurements

\begin{tabular}{|l|l|}
\hline Variable & Measurement \\
\hline Board size & Number of director in the board \\
\hline Independent director & Number of Independent members / Total Number of members (Board Size). \\
\hline $\begin{array}{l}\text { Duality of chairman and CEO } \\
\text { positions }\end{array}$ & Dummy Variable equal to 1 if CEO is also Board Chairman and 0 otherwise \\
\hline Institutional investors & Percentage of directors representing institutional shareholders on the board \\
\hline Foreign director & Percentage of non-Jordanian directors on the board \\
\hline Firm size & Natural logarithm of total assets \\
\hline Firm profitability & Return on assets ( Net operating profit divided by total assets ) \\
\hline Firm leverage & Ratio of the book value of total liabilities to total assets \\
\hline Audit Firm & Dummy Variable equal to 1 if audit firm is one of the big four and 0 otherwise \\
\hline
\end{tabular}

\section{Theoretical model}

For the purpose of empirical analysis, this study uses descriptive analysis and panel data (Fixed Effect) linear multiple regression as the underlying statistical tests. A descriptive analysis of the data is conducted to obtain sample characteristics. The multiple regression analysis is performed on the dependent variable dividends payout ratio, to test the relationship between the independent variables with dividends pay-out. Table 1 shows the variables and their description in this study. The regression models utilized to test the relationship between the board characteristics and firm dividends pay-out as follows:

DPSit $=\alpha 0+\alpha$ BBDSIZEit $+\alpha 2$ BODINDit $+\alpha 3$ INSINit $+\alpha 4$ CEODULit $+\alpha 5$ BODNATit $+\alpha 6$ FSIZEit $+\alpha 7$ FLEVit $+\alpha 8$ PROFit $+\alpha 9$ AUDit + Eit

Where:

DPS : Dividends Per Share.

BODSIZE : Board size.

BODIND : Percentage of non-executive directors.

INSIN : Institutional investors.

CEODUL : Duality of CEO and chairman positions.

BODNAT : Board Nationality FOR DIR

FSIZE : Firm Size.

PROF : Firm Profitability.

FLEV : Firm's Financial leverage.

AUD: Audit firm

$\alpha 0$ : Intercept.

$\alpha$ 1-9: Variables coefficients.

e : Error term.

i : Represents the observation (Firm).

$\mathrm{t}$ : Represents the time (year).

\section{Finding and discussion}

The descriptive analysis for the dependent and the independent and control variables of this study are presented in Table (2). The descriptive statistics include the minimum value, maximum value, mean, and standard deviation for each variable.

Table 2: Descriptive statistics

\begin{tabular}{|l|l|l|l|l|}
\hline Variables & Mean & Std.Dev. & Min & Max \\
\hline DPS & 0.0587 & 0.107 & 0 & 0.65 \\
\hline Board Size & 7.849 & 2.322 & 4 & 13 \\
\hline Independent director & 4.896 & 2.647 & 0 & 13 \\
\hline Institutional investors & 3.57 & 2.277 & 0 & 11 \\
\hline Director nationality & 0.657 & 1.142 & 0 & 7 \\
\hline Firm Size & 7.406 & 0.619 & 6.124 & 9.524 \\
\hline Leverage & 0.354 & 0.295 & 0.0039 & 2.275 \\
\hline ROA & -0.001 & 0.108 & -0.636 & 0.432 \\
\hline
\end{tabular}

*Sample size $(n)=318$ firm year observations during the years $2007-2017$, based on the availability of data.

As seen from Table 2, the dependent variable Dividends per Share (DPS) has a mean of (0.0587), with a standard deviation of (0.1076), while the minimum value reaches $(0)$ and the maximum value reaches $(0.65)$. 
As for the independent variables, the board size mean is about (8) members with a standard deviation of (2) members while the minimum value reaches (4) members and the maximum value reaches (13) members this indicate that most of sample companies apply corporate governance code. The next mean value is related to the independent directors as shown in the table 2 which is about (5) board members $\sim$ near to two third of board size mean , with standard deviation of (3) members, while the minimum value (0) members and the maximum value (13) members this result indicate that most of sample companies adhere in applying corporate governance code. The next mean value is related to the institutional investors in board as shown in the table 2 which is about (4) members, with standard deviation (2) members, while the minimum value was (0) members and the maximum value (11) members. The next variable is the director nationality (Non-Jordanian) that have a mean of about (1) member, with a standard deviation of (1) member, while the minimum value (0) members and the maximum value (7) foreign members. Firm size variable has a mean of (7.406) with standard deviation (0.619) and minimum value (6.124), the maximum value is (9.524). The next mean value is related to leverage as shown in the table 2 which is $(0.354)$, with standard deviation $(0.295)$, while the minimum value was $(0.0039)$ and the maximum value (2.275) this indicate that the sample companies on average depends on equity not in debt in financing. The final mean value is related to ROA as shown in the table 2 which is $(-0.001)$, with standard deviation (0.108), while the minimum value was (-0.636) and the maximum value $(0.432)$ and this give an evidence of that the sample companies on average faces losses.

Table (3) provides descriptive information about the dummy variables included in the regression model. It can be seen from the table that $64.8 \%$ of the sampled companies audited by local companies and $35.2 \%$ of companies audited by big four companies on the other hand $82 \%$ of the sampled companies haven't CEOs duality, and $18 \%$ of sampled companies have a CEO Duality.

Table 3: Frequencies of dummy variables

\begin{tabular}{|l|l|l|c|}
\hline Variable & Type & Frequencies & Percentage \\
\hline \multirow{2}{*}{ Audit Firm } & Big Four & 112 & $35.2 \%$ \\
\cline { 2 - 4 } & Local & 206 & $64.8 \%$ \\
\hline \multirow{2}{*}{ CEO Duality } & Duality & 57 & $18 \%$ \\
\cline { 2 - 4 } & No Duality & 261 & $82 \%$ \\
\hline
\end{tabular}

This study uses panel data analysis to examine the association between the independent variables and the dependent variable. There are some assumptions that have to be satisfied before the data is analysed: normality, multicollinearity, autocorrelation, Heteroskedasticity and unit root. To test the effect of independent variables (Bord size, independent director, Institutional investors, CEO Duality, Foreign director, Firm size, leverage and ROA) on the dividend Per share (DPS).

\section{Multicollinearity}

The aim of this analysis is to investigate any multicollinearity problems between the independent variables and the association among dependent variables (Shukeri \& Nelson, 2010). According to Hair et al. (2010) and Tabachnick and Fidell (2007), a multicollinearity problem occurs if the correlation among independent variables is above 0.80 or 0.75 for some of it. Two methods are used to discover multicollinearity problems in the model of this study: Pearson Correlation (correlation matrix).

Table (4) shows the Pearson Correlation among the variables. All the correlation coefficients among the independent variables in the correlation matrix are less than 0.80 . This implies that multicollinearity is not a problem in the regression model.

Table 4: Pearson Correlation among the variables

\begin{tabular}{|l|l|l|l|l|l|l|l|l|l|}
\hline & AUD & FSIZE & FLEV & PROF & BODSIZE & CEO DUL & FORDIR & INSIN & BODIND \\
\hline AUD & 1 & & & & & & & & \\
\hline FSIZE & 0.522 & 1 & & & & & & & \\
\hline FLEV & 0.001 & 0.167 & 1 & & & & & & \\
\hline PROF & 0.107 & 0.234 & -0.512 & 1 & & & & & \\
\hline BODSIZE & 0.152 & 0.429 & -0.068 & 0.138 & 1 & & & & \\
\hline CEO DUL & -0.104 & 0.064 & 0.022 & 0.065 & -0.007 & 1 & & & \\
\hline FORDIR & 0.435 & 0.195 & -0.002 & -0.049 & -0.008 & -0.104 & 1 & & \\
\hline INSIN & 0.182 & 0.365 & -0.037 & -0.023 & 0.392 & 0.248 & 0.168 & 1 & \\
\hline BODIND & -0.005 & 0.266 & 0.062 & 0.027 & 0.545 & -0.095 & 0.054 & 0.266 & 1 \\
\hline
\end{tabular}

Note: AUD: Audit Firm, FSIZE: Firm Size, FLEV: leverage, BODSIZE: Board Size, CEODUL: Duality of CEO and chairman position, FORDIR: Foreign director, INSIN: Institutional Investors, BODIND: Independent Director. 


\section{NORMALITY}

The study used Kolmogrov Semirnov test of normality among regression residuals to test the normality in the regression formed by this study (Hair et al., 2010) suppose that the normality problem exist when the probability in the Kolmogrov Semirnov test is lower than 5\%, Table (5) provide evidence about the residuals normality and its shows that the residuals in regression are normally distributed. Moreover, this study covers the whole sample and involves a large amount of data (318 observations), and the normality assumption is probably not seriously affected.

Table 5: Test of Kolmogrov-Semirnov

\begin{tabular}{|l|l|l|}
\hline Variables & $\mathbf{C h}^{2}$ & Sig \\
\hline Residuals $\varepsilon$ & 5.23 & 0.0732 \\
\hline
\end{tabular}

\section{Unit Root Test}

In statistics, a unit root test examines whether a time series variable is non-stationary and possesses a unit root. The null hypothesis is generally defined as the presence of a unit root depending on the test used. Stationary of series is a prerequisite before conducting any econometric work. Granger and Newbold (1974) discussed that working with non-stationary variables may bring spurious results that may lead to incorrect results. The study uses unit root test namely ADF (Augmented Dickey-Fuller). Therefore, table (6) presents the unit root test for the explanatory variables and DPS. It shows all explanatory variables and DPS are stationary.

Table 6: The Unit Root Test

\begin{tabular}{|l|l|l|}
\hline Variables & T-Statistic & P-Value \\
\hline Firm Size & -6.097 & 0.000 \\
\hline Leverage & -14.023 & 0.000 \\
\hline ROA & -15.289 & 0.000 \\
\hline DPS & -6.0793 & 0.000 \\
\hline Board Size & -20.266 & 0.000 \\
\hline Institutional investors & -2.383 & 0.000 \\
\hline Board Independence & -2.515 & 0.000 \\
\hline
\end{tabular}

\section{AUTOCORRELATION}

The presence of autocorrelation is checked using Wooldridge statistics, a test to detect the existence of autocorrelation in the residuals from a regression analysis. According to Kazmier (1996), the value for Wooldridge statistics more than 5\% indicates the presence of a strong series problem of correlation among errors, and a value less than 5\% indicates that there is no series problem of autocorrelation. As presented in Table (7), the value of Wooldridge P-value of the Models is 0.001 Thus; there is no problem of autocorrelation among errors in regression.

Table 7: Test of Wooldridge

\begin{tabular}{|l|l|l|}
\hline & F & Sig \\
\hline Error Term & 19.72 & 0.0001 \\
\hline
\end{tabular}

\section{Heteroscedasticity}

As for test for homoscedasticity, it assumes that the dependent variable shows an equal degree of variance throughout the predictor variables' range. This is a desirable result as the dependent variable variance should not be concentrated on a limited range of the independent variables. In this context, violation of homoscedasticity refers to heteroscedasticity. The latter condition has a tendency to make the coefficient estimate to be underestimated, and in some cases, it makes insignificant variables seem significant (Hair et al., 2010). In this study, homoscedasticity and the independence of error terms were examined with Likelihood Ratio test, in the heteroscedasticity test using this method the probability of residuals should be less than $5 \%$ level of significance. Table 8, shows the test of heteroscedasiticity, and indicate that there is no problem of heteroscedasticity. Tables 8: Test of Heteroscedasticity

\begin{tabular}{|l|l|l|}
\hline & LR Ch2 & Sig \\
\hline Residual & 544.94 & 0.000 \\
\hline
\end{tabular}

\section{Regression Analysis}

This section discusses the results of the regression analysis between the independent variables and dividend per share (DPS). To test the hypotheses, the multiple regression analysis is used to examine the association between board composition and dividend per share (DPS). The test shows that panel data analysis is better than pooled ordinary least square regressions. The chi2 of L-M test is found to be statistically significant which suggest that Pooled analysis results will not be efficient So, the study used the panel-Data analysis to test the empirical Model in the current study using a fixed effect model and Random effect Model. However, the result of Hausman test shows that fixed effect Model will be the more appropriate for the study data set. Therefore, For the purpose of accomplish the study objectives; discussion will be restricted to the model that has been found more efficient in 
Table (9).

Table 9: Test of Regressions

\begin{tabular}{|c|c|c|c|c|}
\hline Dependent Variables & Explanatory Variables & Beta & $\mathbf{T}$ & Sig \\
\hline \multirow{17}{*}{ DPS } & Audit firm & -0.084 & -2.77 & $0.006 * * *$ \\
\hline & Board Size & 0.0121 & 2.1 & $0.037 * *$ \\
\hline & Independent director & -0.0071 & -2.5 & $0.013 * *$ \\
\hline & Institutional investors & -0.016 & -2.69 & $0.008 * * *$ \\
\hline & CEO DUL & 0.0398 & 1.53 & 0.128 \\
\hline & Director nationality & 0.0056 & 0.57 & 0.57 \\
\hline & Firm Size & 0.0005 & 0.01 & 0.989 \\
\hline & Leverage & 0.0535 & 1.44 & 0.152 \\
\hline & ROA & 0.349 & 5.85 & $0.000 * * *$ \\
\hline & Cons. & 0.0517 & 0.17 & 0.866 \\
\hline & $\mathrm{F}$ & 9.36 & & \\
\hline & Sig & $0.000 * * *$ & & \\
\hline & $\mathrm{R}^{2}$ & $23.12 \%$ & & \\
\hline & \multirow{2}{*}{ Hausman test } & \multicolumn{3}{|c|}{ Chi2 statistic $=18.35$} \\
\hline & & \multicolumn{3}{|c|}{ Prob. $>$ Chi $2=0.0187 * *$} \\
\hline & \multirow{2}{*}{ L-M Test } & \multicolumn{3}{|c|}{ Chi2 statistic $=57.70$} \\
\hline & & \multicolumn{3}{|c|}{ Prob. $>$ Chi $2=0.000 * * *$} \\
\hline
\end{tabular}

Denote variable is significant level at $* * * 1 \%, * * 5 \%$, and $* 10 \%$

Table (9) suggests that the panel data analysis - Fixed effect model is more appropriate to estimate the impact of board composition with $\mathrm{R}^{2}=23.12 \%$, in addition, the value of F-Statistics is (9.36) and Sig. value of (0.000) which indicates acceptance of the statistical model and the main hypothesis which states "There is a significant impact of board composition on the dividends pay out of Jordanian industrial companies listed on the ASE"

Also table (9) shows that there is a positive significant effect between board size and DPS value where $(\mathrm{t}=$ 2.10 , Sig $=0.037)$ at the $5 \%$ level. This result indicate when the board size increase the DPS will increase. On the other hand there is a negative significant effect between Independent director and DPS value where $(t=-2.50$, $\mathrm{Sig}=0.013)$ at the $5 \%$ level. This result indicate when the independent director increase the DPS will decrease. Table 9 also shows that There is a negative significant effect between Institutional investors and DPS value where $(\mathrm{t}=-2.69, \mathrm{Sig}=0.008)$ at the $1 \%$ level. This result indicate when the Institutional investors increase the DPS will decrease. On the other hand there is no significant effect between duality and DPS value where $(t=$ 1.53, Sig $=0.128)$. On the other hand There is no significant effect between Foreign Director and DPS value where $(\mathrm{t}=0.57$, Sig $=0.570)$. There is no significant effect firm size and DPS value where $(\mathrm{t}=0.01$, Sig $=$ 0.989). There is no significant effect leverage and DPS value where $(t=1.44, \operatorname{Sig}=0.152)$. There is a positive significant effect between return on assets $(\mathrm{ROA})$ and DPS value where $(\mathrm{t}=5.85, \mathrm{Sig}=0.000)$ at the $1 \%$ level. This result indicate when the ROA increase the DPS will increase. Also it shows that there is a negative significant effect between Audit firm and DPS value where $(t=-2.77, \mathrm{Sig}=0.006)$ at the $1 \%$ level. This result indicate if audit Firm is one of big four firm the DPS will decrease.

\section{CONCLUSION}

As stated in chapter one, the main objective of this study was to examine the impact of Board Composition on Corporate dividends pay-out for a sample of manufacturing companies listed on the ASE for the period (20072017). To accomplish this objective, dividends per share was used as measures dividends pay-out.

The results of the multiple regression analysis showed relatively moderate explanatory power for the model where the $\mathrm{R}^{2}$ value was $23.12 \%$ of the variations in companies' dividends pay-out was explained by the independent variables incorporated in the model.

As for the independent variables, the results of the regression analysis indicate that there is a positive effect of board size on DPS. This result indicate when the board size increase the DPS will increase because the board members investors in the company. Also there is a negative effect of Independent director on DPS. This result indicate when the independent director increase the DPS will decrease. Because independent members seek to achieve the interests of the company rather than their personal interests. Also there is a negative effect of Institutional investors on DPS. This result indicate when the Institutional investors increase the DPS will decrease. Because Institutional investors look to the future of the company instead of making a current profit. There is a positive effect of return on assets (ROA) on DPS at the 1\% level. This result indicate when the ROA 
increase the DPS will increase. Because when companies increase their profits they have achieved the required reserve level and distribute the rest of the profits. Also there is a negative effect of Audit firm on DPS at the $1 \%$ level. Because the large audit firms want to keep companies at a high rate of reserve. On the other hand there is no significant effect of duality, Director Nationality, firm size and leverage on DPS.

\section{References}

Joshua Abor, Vera Fiador, (2013) "Does corporate governance explain dividend policy in Sub-Saharan Africa?", International Journal of Law and Management, Vol. 55 Issue: 3, pp.201-225

John, K. and Senbet, L.W. (1998), "Corporate governance and board effectiveness", Journal of Banking \& Finance, Vol. 22, pp. 371-403.

Abdurrahman Ali Al-Twaijry, (2007) "Dividend policy and payout ratio: evidence from the Kuala Lumpur stock exchange", The Journal of Risk Finance, Vol. 8 Issue: 4, pp.349-363,

Abdelkarem,N.,(2013),empirical investigation of linkage between the degree of companies with corporate governance and profitability : evidence from palstine exchange listed firm . third conference of the banking and financial sciences, yarmouk university, on corporate governance .no .17-18,pp.746-764

Adjaoud, F., and Ben-Amar, W. 2010. Corporate Governance and Dividend Policy: Shareholders' Protection or Expropriation? Journal of Business Finance \& Accounting, 37 (5) \& (6): 648-667

Mehdi Mili Jean-Michel Sahut and Frédéric Teulon" Do corporate governance and ownership structure impact dividend policy in emerging market during financial crisis?" Journal of Applied Accounting Research, 2017, vol. 18, issue 3, 274-297

Elmagrhi H. Muhammad, Collins G. Ntim, Richard M. Crossley, John K. Malagila, Samuel Fosu, Tien V. Vu, (2017) "Corporate governance and dividend pay-out policy in UK listed SMEs: The effects of corporate board characteristics", International Journal of Accounting \& Information Management, Vol. 25 Issue: 4, pp.459-483

Abdel Razeg Abdel Monsif Azzozland Basheer Ahmad Khamees ,2016 “The Impact of Corporate Governance Characteristics on Earnings Quality and Earnings Management: Evidence from Jordan Jordan" Journal of Business Administration, Volume 12, No. 1

Musa Shehu, 2015" Board Characteristics and Dividend Payout: Evidence from Malaysian Public Listed Companies" Research Journal of Finance and Accounting ISSN 2222-1697 (Paper) ISSN 2222-2847 (Online) Vol.6, No.16, 201

Benjamin Samuel Jebaraj, Mat Zain Mazlina, (2015) "Corporate governance and dividends payout: are they substitutes or complementary?", Journal of Asia Business Studies, Vol. 9 Issue: 2, pp.177-194

Yarram Subba Reddy, Dollery Brian, (2015) "Corporate governance and financial policies: Influence of board characteristics on the dividend policy of Australian firms", Managerial Finance, Vol. 41 Issue: 3,pp.267-285

Paul McGuinness \& Kevin Lam \& João Vieito, 2015. "Gender and other major board characteristics in China: Explaining corporate dividend policy and governance," Asia Pacific Journal of Management, Springer, vol. 32(4), pages 989-1038, December

La-Porta, R., Lopez-de-Silanes, F., Shleifer, A. and Vishny, R.W. (2000), “Agency problems and dividend policies around the world", Journal of Finance, Vol. 55 No. 1, pp. 1-33.

Jensen, Michael C., and William H. Meckling. (1976). Theory of the Firm: managerial Behavior, Agency Cost, and Ownership Structure. Journal of Financial Economics Vol. 3(4) (Oct), pp. 305-60

Schulder, W., \& Lubatkin, M. H., \& Dino, R. N. (2002). Exploring the agency consequences of ownership dispersion among inside directors at family firms. The Academy of Management Journal, 46(2), 179-194.

Miller, M., \& Modigliani, F. 1958. Dividend policy, growth and the valuation of shares. Journal of Business, 34 : 411-433.

Malonis,J.A.(2000) Agency Theory. In Encyclopedia of Business. Retrieved May 17, 2011 from http://www.enotes.com/biz-encyclopedia/agency-theory

Myers , S., Majluf ,N., (1984) corporate financing and investment decisions when firms have information that investors do not have .Journal of financial Econmics 13,187-221

Laffont, J.J., \& Martimort D .(2001)The Theory of Incentives: The Principal - Agent Model. Princrton Universty Press.

Keenan, J. P., Barnacz, A. L., Johnson, A. \& Constantino, P.(2004). Schizotypal personality traits and deception: The role of self-awareness. Schizophrenia Research, 70, 115-116.

Riaz, S., Naseem, M. A., Xiaoming, S., \& Rehman, R. U. (2017). Board attributes and financial performance: the evidence from an emerging economy. The journal of developing areas, 51(3), 281-297.

Al-Rahahleh, A. S. (2015). Corporate governance quality, board gender diversity and corporate dividend policy: Evidence from Jordan. Australasian Accounting, Business and Finance Journal, 11(2), 86-104.

Seth, A. \& Rediker, K. J.1995. Boards of directors and substi tution effects of alternate governance mechanisms. Strategic Management Journal, 16: 85-99. 
Janssen, M., Lee, J., Bharosa, N., \& Cresswell, A. (2009). Advances in multi-agency disaster management: Key elements in disaster research. Information Systems Frontiers, 12(1), 1-7.

Kreps DM. 1990. Corporate culture and economic theory. In Perspectives on Political Economy, Alt JE, Shepsle KA (eds). Cambridge University Press: Cambridge; 90-143.

Shukeri Norwahida, S. \& Nelson Puat, S. (2010). Corporate governance and audit report timeliness: evidence from Malaysia. In Accounting in Asia (pp. 109-127). Emerald Group Publishing Limited.

Hair Jr, J. F., Wolfinbarger, M., Money, A. H., Samouel, P., \& Page, M. J. (2010). Essentials of business research methods. Routledge.

Tabachnick, B. G., Fidell, L. S., \& Ullman, J. B. (2007). Using multivariate statistics (Vol. 5). Boston, MA: Pearson.

Granger, C. W. \& Newbold, P. (1974). Experience with forecasting univariate time series and the combination of forecasts. Journal of the Royal Statistical Society: Series A (General), 137(2), 131-146.

Kazmier, L. J. (1996). Schaum's outline of theory and problems of business statistics. Schaum's Outline Series. 